\title{
DETERMINATION OF UREAPLASMA UREALYTICUM AND ANTIBIOTIC SUSCEPTIBILITY IN SEXUALLY ACTIVE WOMEN WITH DIFFERENT METHODS
}

\author{
CINNSL YÖNDEN AKTIFF KADINLARDA UREAPLASMA UREALYTICUM VE \\ ANTIBBIYOTIK DUYARLILIĞININ FARKLI YÖNTEMLERLE BELIRLENMESI
}

\author{
Şükran ÖZTÜRK ${ }^{*}$ (D), Sulhiye YILDIZ ${ }^{2}$ \\ ${ }^{1}$ Zonguldak Bulent Ecevit University, Faculty of Pharmacy, Department of Pharmaceutical \\ Microbiology, 67600, Zonguldak, Turkey \\ ${ }^{2}$ Lokman Hekim University, Faculty of Pharmacy, Department of Pharmaceutical Microbiology, \\ 06510 Ankara, Turkey
}

\section{ABSTRACT}

Objective: In this study, the presence of Ureaplasma urealyticum (U.urealyticum) in vaginal and urine samples taken from sexually active women was investigated and antibiotic susceptibilities were determined with culturing bacteria and using kits.

Material and Method: The vaginal and urine samples taken from 110 women who applied to Başkent University Ankara Gynecology and Obstetrics Clinic were included in this study. U. urealyticum was investigated by the culture method with using two different test kits [Mycoplasma IES (IES-Autobio, China) and Mycoplasma IST2 (IST2) Biomereux, France] and Mycoplasma Agar. Antibiotic susceptibilities of isolates were also determined.

Result and Discussion: We compared the results of (IES) and (IST2) used for U. urealyticum detection in 220 clinical samples. $U$. urealyticum was found to be positive in $82(74,5 \%)$ by classical culture method. $U$. urealyticum was detected at a rate of $46.8 \%$ with the IST 2 and 53.6\% with the IES. As a result of the comparison of culture method and commercial kits,it was determined that the IES kit provides a fast and accurate identification in the detection of U.urealyticum, a fast and reliable result in the detection of antibiotic resistance.A significant difference was found in the detection rate of U. urealyticum of the IES compared to the other commercial kit.It was observed that the detection rate of $U$. urealyticum with the kit from vaginal were significantly higher than urine samples.

Keywords: Antibiotic susceptibility, commercial kit, culture, U. urealyticum

\footnotetext{
* Corresponding Author / Sorumlu Yazar: Şükran Öztürk

e-mail / e-posta: sukranozturk79@gmail.com, Phone / Tel.: +905056652387
} 
ÖZ

Amaç: Bu çalışmada, cinsel yönden aktif kadınlardan alınan vajinal ve idrar örneklerinde Ureaplasma urealyticum (U.urealyticum) varlığı, kültür ve kitlerle araştırılmış, ticari kitler kullanılarak da antibiyotik duyarlılıkları belirlenmiştir.

Gereç ve Yöntem: Başkent Üniversitesi Ankara Kadın Hastalıkları ve Doğum Kliniği'ne başvuran 110 kadından alınan vajinal ve idrar örnekleri ile çalışma gerçekleştirilmiştir. U. urealyticum'un Mycoplasma IES (IES-Autobio, China) ve Mycoplasma IST2 (IST2-Biomereux, Fransa) olarak bilinen iki farkl test kiti ile tespiti yapılmış ve antibiyotik duyarlılıkları belirlenmiştir. Ayrıca Mycoplasma Agar kullanılarak kültür yöntemiyle de varlı̆̆l araştırılmıştır.

Sonuç ve Tartışma: U. urealyticum tespiti için 220 klinik örnek kullanılmıştır. IES ve IST2 ticari kitleri kullanılarak yapılan tespit sonuçları ile Mycoplasma Agar besiyeri kullanılarak klasik kültür yöntemi ile yapılan çalışma sonuçları karşılaştırılmıştır. Buna göre; kültür yöntemiyle $82(\% 74,5)$ hastada U. urealyticum pozitif bulunmuş olup, U.urealyticum, IST 2 ile \%46,8, IES ile $(\% 53,6)$ oranında tespit edilmiştir. Kültür yöntemi ile ticari kitlerin karşılaştırılması sonucunda, IES kitinin U. urealyticum tespitinde ve antibiyotik duyarlılıklarının saptanmasında hızlı ve doğru bir tanımlama sağladı̆̆ sonucuna varılmıştır. IES kitinin $U$. urealyticum tespit oranında diğer ticari kite göre anlamlı derecede iyi tespit yaptığı ortaya konmuş olup, vajinal örneklerden U. urealyticum tespit oranının, idrar örneklerinden anlamlı derecede yüksek olduğu görülmüştür.

Anahtar kelimeler: Antibiyotik duyarlılı̆̆ı, kültür, ticari kit, U. urealyticum

\section{INTRODUCTION}

Mycoplasma is a bacteria without a cell wall and has the smallest cells among prokaryotes and self-copying. They can be cultured in vitro in a medium having both RNA and DNA and live as both parasites and saprotrophs. [1]. Ureaplasma urealyticum (U. urealyticum) is potentially pathogenic bacterial species that usually associated with urogenital and respiratory system diseases, sexually transmittedand have no peptidoglycan cell wall. Hence, they are found to be responsible of infertility, prematurity, recurrent abortus and newborn respiratory distress. In some studies, U. urealyticum has been shown as one of the factors of infertility seen in men [2]. Laboratory diagnosis of them is relatively complicated since they are very sensitive microorganisms and they require special transport and culture media. Since the infections caused by these microorganisms exhibit importance, proper isolation and identification of these bacteria are required to make proper and reliable [3,4].

The aim of this study was to determine the rate of $U$. urealyticum from vaginal and urinary samples obtained from 110 sexually active women from Başkent University Ankara Hospital Obstetrics and Gynecology Clinic. Also to compare the results and detection ability of different clinical methods including culture method with Mycoplasma agar media, commercially available kit methods Mycoplasma IST 2 and Mycoplasma IES.

\section{MATERIAL AND METHOD}

\section{Study Design and Sample Collection}


We used two commercially available diagnostic kits; Mycoplasma IES (IES) and Mycoplasma IST-2 (IST-2). U. urealyticum ATCC 27618 strain was used as control.

A total of 220 clinical samples consist of 110 urine and 110 vaginal were included in the study. These samples were collected from 110 sexually active women in Obstetrics and Gynecology Clinic, Başkent University Ankara Hospital, Ankara, Turkey. All samples were analyzed by the classical culture method and two commercial diagnostic kits method. The vaginal samples were collected with steril cotton swaps and urinary samples with steril container. Then samples were transffered to suitable diluent vial (supplied with the diagnostic kits) that contains selective agents to inhibit the growth of other microbes present in the sample and transported in a suitable medium that containing urea/ arginine diluent supplied with the Mycoplasma IST-2 and Mycoplasma IES diagnostic kits, stored either at $4{ }^{\circ} \mathrm{C}$ for culture. For the detection of $U$. urealyticum in the samples, in-vitro culture, and diagnostic kit methods were used. If the presence of $U$. ueralyticum detected by the culture method, it was confirmed by the two commercial kits. Included in the kit content, the sensitivity of the samples to various antibiotics was also determined.The susceptibility strip contained 11 antibiotics (Pristinamycin (PRI), Minocycline (MIN), Roxythromycin (ROX), Clindamycin (CLI), tetracycline (TET), josamycin (JOS), Ofloxacin (OFL), ciprofloxacin (CIP), clarithromycin (CLA), erythromycin (ERY) and Levofloxacin (LEV)) in IES kit and 9 antibiotics in IST-2 kit (Pristinamycin (PRI), doxycycline (DOT), tetracycline (TET), josamycin (JOS), Ofloxacin (OFL), ciprofloxacin (CIP), clarithromycin (CLA), erythromycin (ERY) and azithromycin (AZI)).

\section{Culture Methods}

Mycoplasma Agar Medium (MAM) (CM0401, Oxoid) is a basic medium that can be used for the isolation and cultivation of mycoplasmas from clinical specimens after enrichment with a supplement. MAM was used for the detection of $U$. urealyticum by classical culture method. In $1 \mathrm{~L}$ of distilled water $35.5 \mathrm{~g}$ agar were dissolved and distribute in $80 \mathrm{~mL}$ volumes. Sterilized by autoclaving at $121{ }^{\circ} \mathrm{C}$ for 15 min. Cool to $50{ }^{\circ} \mathrm{C}$ and one vial of Mycoplasma Supplement-G SR0059 (Oxoid) reconstituted were added to sterilized medium as directed. Mycoplasma species are grown at $\mathrm{pH}$ 7.4-8.0, but U.urealyticum (T-strains)* prefer pH 6.0-6.5 for growing in Mycoplasma Agar [5]. Mycoplasma spp. colonies were expected to appear by tissue culture microscopy as typical fried egg [6,7].

\section{Kits Methods (IES and IST-2)}

Vaginal and urine samples, collected by the suitable technical, were inoculated to the two different commercial kits: IES and IST-2.

The kits were used for the identification, detection, enumeration, and antimicrobial susceptibility testing of $U$. urealyticum in the samples following to the manufacturer's instructions. The kit reagents were mixed with the samples and incubated at $36-38{ }^{\circ} \mathrm{C}$ for $24-48 \mathrm{~h}$. At the end of the incubation period, the color change of the medium from yellow to deep pink was considered positive for $U$. urealyticum. 
The IST-2 kit contains R1 (transport medium) and R2 (selective growth medium) tubes. All samples were collected with sterile swab. Swabs were taken into the liquid transport medium R1 and delivered to the clinical laboratory within $4 \mathrm{~h}$ of collection for the identification of $U$. urealyticum. R1 swabs were transferred to the R2 medium after vortexed for $10 \mathrm{sec}$. Than the R2 medium was then dispensed into wells to detect the presence of mycoplasmas and the wells were overlaid with mineral oil to prevent drying. The kits were incubated at $37^{\circ} \mathrm{C}$ for $48 \mathrm{~h}$ and observed for any color change at $24 \mathrm{~h}$ and $48 \mathrm{~h}$. The color alteration from yellow to orangered in the culture medium is related to an increase in $\mathrm{pH}$ and remarks growth of mycoplasmas. The determination of orange to red color of the antimicrobial susceptibility well shows the resistance of mycoplasmas to an antimicrobial agent. From the R2 positive tube, $0.1 \mathrm{~mL}$ was also inoculated onto Mycoplasma agar medium with Supplement G (Oxoid). Three hundred $\mu \mathrm{L}$ of the inoculation suspension was transffered into the medium. Then, the suspension (100 $\mu \mathrm{L}$ ) was inoculated into the wells of the strip. Each strip well was covered by mineral oil. The incubation period was applied at $37{ }^{\circ} \mathrm{C}$ for $24 \mathrm{~h}$. The appearance of red color indicated positive reaction and microbial growth.

In addition, all samples were inoculated on blood agar. To determine that the Proteus spp. for differentiate from $U$. urealyticum and to reveal the status of interference with Proteus spp colonies cultured on blood agar. All positive samples were confirmed as $U$. urealyticum.

\section{Statistical Analysis}

The suitable sample size was determined on the basis of the kappa statistics for power of test 0.80. Descriptive statistics were presented as frequency and percentages for categorical variables (Table 2).

For the determination the effect of independent variables on the $U$. urealyticum asset that a generalized estimating equation (GEE) was used. Positive predictive value, negative predictive value, sensitivity, and specificity values were calculated for IES, IST-2 by agar culture data. In addition, for the samples (164 positive), the relationship between the results of the vaginal and urinary samples obtained with the IES and IST-2 kits was analyzed by chi-square test. Significance level $(\alpha)$ of the tests was accepted to be $\mathrm{p}<0.05$. The SPSS software, version 21.0 (SPSS Inc., Chicago, IL, USA), and R 3.4.2 [https://www.r-project.org/] were used for statistical analyses.

\section{RESULT AND DISCUSSION}

A total of 110 sexually active women (urine and vaginal, a total of 220 samples) were included in this study and U. urealyticum was detected positive with Mycoplasma agar plates in 82 (74,5\%) patients. One hundred and three positive results was detected in 220 samples $(46,8 \%)$ as $U$. urealyticum by Mycoplasma IST 2 kit and 118 positives in 220 samples $(53,6 \%)$ by Mycoplasma IES kit. The 
antibiotic resistance rates of isolates were evaluated by using the Mycoplasma IES assay as 3\% for levofloxacin, $19 \%$ for erythromycin, $20 \%$ for tetracycline, and $6 \%$ for ciprofloxacin. With the Mycoplasma IST 2 assay resistance rates were 17\% to tetracycline, $9 \%$ to ciprofloxacin, $11 \%$ to erythromycin. All isolates were found susceptible to pristinamycin, josamycin, and doxycycline.

The Mycoplasma IES kit was found to be accomplished compared to other commercial culturebased assays for a rapid and accurate identification of U. urealyticum and detection of resistance. Also, the detection rates of $U$. urealyticum was found higherin vaginal specimens than urine samples (Table $1)$.

Table 1. Distribution of positive specimens by origin and kit types

\begin{tabular}{|l|c|c|c|c|c|c|}
\hline Sample Type & \multicolumn{2}{|c|}{ IES } & \multicolumn{2}{c|}{ IST-2 } & \multicolumn{2}{c|}{ Culture } \\
\hline & positive & negative & positive & negative & positive & negative \\
\hline Vaginal (110) & $67(61 \%)$ & $15(14 \%)$ & $58(53 \%)$ & $24(22 \%)$ & $82(74 \%)$ & 0 \\
\hline Urine (110) & $51(46 \%)$ & $31(28 \%)$ & $45(41 \%)$ & $37(34 \%)$ & $82(74 \%)$ & 0 \\
\hline Total (220) & $118(54 \%)$ & $46(21 \%)$ & $103(47 \%)$ & $61(28 \%)$ & $164(74 \%)$ & 0 \\
\hline
\end{tabular}

Diagnostic test evaluation results according to sample types are shown in Table 2. When the results are evaluated; For IST 2 and IES methods, vaginal sample sensitivity, NPV and accuracy values are higher than urine sample values.

Table 2. Diagnostic test evaluation IST-2, IES and agar culture by sample type

\begin{tabular}{|l|c|c|c|}
\hline \multicolumn{1}{|c|}{ Statistic } & IST 2 & IES & Agar Culture \\
\hline Sensitivity (VS) & $88.89 \%$ & $97.22 \%$ & $100.00 \%$ \\
\hline Sensitivity (US) & $55.56 \%$ & $63.89 \%$ & $100.00 \%$ \\
\hline Specificity (VS) & $100.00 \%$ & $100.00 \%$ & $100.00 \%$ \\
\hline Specificity (US) & $100.00 \%$ & $100.00 \%$ & $100.00 \%$ \\
\hline Positive Predictive Value (PPV) (VS) & $100.00 \%$ & $100.00 \%$ & $100.00 \%$ \\
\hline Positive Predictive Value (PPV) (US) & $100.00 \%$ & $100.00 \%$ & $100.00 \%$ \\
\hline Negative Predictive Value (NPV) (VS) & $94.87 \%$ & $98.67 \%$ & $100.00 \%$ \\
\hline Negative Predictive Value (NPV) (US) & $82.22 \%$ & $85.06 \%$ & $100.00 \%$ \\
\hline Accuracy (VS) & $96.36 \%$ & $99.09 \%$ & $100.00 \%$ \\
\hline Accuracy (US) & $85.45 \%$ & $88.18 \%$ & $100.00 \%$ \\
\hline
\end{tabular}

*VS: Vaginal Sample *US: Urine Sample

Diagnostic test evaluation results according to kit types were shown in Table 3. The results were evaluated IES of sensitivity, NPV and accuracy values $80.56 \%, 91.36 \%, 93.64 \%$ respectively. IST 2 of sensitivity, NPV and values $72.22 \%, 88.10 \%, 90.91 \%$ respectively. IES method has higher sensitivity and accuracy value than IST 2 method. The concordance of IST 2 and IES methods with agar culture method was examined with kappa coefficient. The kappa coefficients were found to be statistically significant and high fit, respectively $(0.778, \mathrm{p}<0.001 ; 0.848, \mathrm{p}<0.001)$. 


\section{Antibiotic Susceptibility of the $\boldsymbol{U}$. urealyticum Isolates with IST-2 Kit}

Samples were also evaluated with IST-2 kit for antibiotic susceptibilities. The greatest sensitivity among all strains was 100\% against pristinamycin (PRI), josamycin (JOS), and doxycycline (DOT). The resistance rates were; $11 \%$ to erythromycin (ERY), $83 \%$ to tetracycline (TET), and the highest resistance was found to ciprofloxacin (CIP) $91 \%$ (Table 4). Minimal inhibition concentrations (MICs)s were performed according to CLSI guidelines (tests repeated two times). MICs were interpreted according to the IST 2 kit criteria (see the legend to Table 4) $[3,8]$.

Table 3: Diagnostic test evaluation, IST- 2, IES and Agar Culture

\begin{tabular}{|l|c|c|c|}
\hline \multicolumn{1}{|c|}{ Statistic } & IST2 & IES & Agar Culture \\
\hline Sensitivity & $72.22 \%$ & $80.56 \%$ & $100.00 \%$ \\
\hline 95\%CI for Sensitivity & $60.41 \%$ to $82.14 \%$ & $69.53 \%$ to $88.94 \%$ & $95.01 \%-100.00 \%$ \\
\hline Specificity & $100.00 \%$ & $100.00 \%$ & $100.00 \%$ \\
\hline 95\%CI for Specificity & $97.54 \%$ to $100.00 \%$ & $97.54 \%$ to 100.00 & $97.54 \%-100.00 \%$ \\
\hline Positive Predictive Value (PPV) & $100.00 \%$ & $100.00 \%$ & $100.00 \%$ \\
\hline Negative Predictive Value (NPV) & $88.10 \%$ & $91.36 \%$ & $100.00 \%$ \\
\hline 95\%CI for NPV & $83.60 \%$ to $91.48 \%$ & $86.85 \%$ to $94.42 \%$ & $100.00 \%$ \\
\hline Accuracy & $90.91 \%$ & $93.64 \%$ & \\
\hline 95\%CI for Accuracy & $86.31 \%$ to $94.36 \%$ & $89.55 \%$ to $96.48 \%$ & $98.34 \%-100.00 \%$ \\
\hline
\end{tabular}

Table 4. Antimicrobial susceptibilities of the $U$. urealyticum isolates with IST-2 kit and MIC values $(\mu \mathrm{g} / \mathrm{mL})$

\begin{tabular}{|l|c|c|c|c|}
\hline \multicolumn{2}{|c|}{ U. urealyticum $\left(\mathbf{n}^{\mathbf{1}=82}\right)$} & $\boldsymbol{S}$ & $\boldsymbol{R}$ \\
\hline & $\boldsymbol{S}$ & $\boldsymbol{R}$ & $\leq 4$ & $\geq 8$ \\
\hline Doxycycline (DOT) & $82(100.0)$ & $0(0)$ & $\leq 2$ & $\geq 8$ \\
\hline Josamycin (JOS) & $82(100.0)$ & $0(0)$ & $\leq 1$ & $\geq 4$ \\
\hline Ofloxacin (OFL & $60(72.5)$ & $22(27,5)$ & $\leq 1$ & $\geq 4$ \\
\hline Erythromycin (ERY) & $73(88.9)$ & $9(11.1)$ & $\leq 4$ & $\geq 8$ \\
\hline Tetracycline (TET) & $68(83.0)$ & $14(17.0)$ & $\leq 1$ & $\geq 2$ \\
\hline Ciprofloxacin (CIP) & $75(91.0)$ & $7(0.9)$ & $\leq 0.12$ & $\geq 4$ \\
\hline Azithromycin (AZI) & $63(76.5)$ & $19(15.6)$ & $\leq 1$ & $\geq 4$ \\
\hline Clarithromycin (CLA) & $69(84.3)$ & $13(10.7)$ & & $\geq 2$ \\
\hline Pristinamycin (PRI) & $82(100.0)$ & $0(0)$ & \\
\hline
\end{tabular}

Mycoplasma IST 2 kit (bioMérieux).U. urealyticum, Ureaplasma urealyticum; S, susceptible; I, intermediate; $R$, resistant. $n^{I}=82$ (patient). Results are $n(\%)$. The breakpoints $(\mu \mathrm{g} / \mathrm{mL})$ according to the Clinical and Laboratory Standards Institute are as follows: Tetracycline $S \leq 4, R \geq 8$; Doxycycline $S \leq 4, R \geq 8$; Azithromycin $S \leq 0.12, R \geq 4$; Clarithromycin $S \leq 1, R \geq 4$; Erythromycin $S \leq 1, R \geq 4$; Josamycin $S \leq 2, R \geq 8$; Ciprofloxacin $S \leq 1, R \geq 2$; Ofloxacin $S \leq 1, R \geq 4$; Pristinamycin $R \geq 2$.

\section{Antibiotic Susceptibility of the $\boldsymbol{U}$. urealyticum Isolates with IES Kit}

The antibiotic susceptibilities of microorganisms were also evaluated by IES kit. Accordingly, all strains showed greatest sensitivity to pristinamycin (PRI) with100\% rate, tetracycline (TET) sensitivity was followed this result with $80 \%$, and $95 \%$ rate was found to josamycin (JOS). The highest antibiotic resistance was seen $97 \%$ to levofloxacin (LEV), 100\% to clindamycin (CLI), 94\% to ciprofloxacin (CIP), and $51 \%$ to roxithromycin (ROX). The resistance to erythromycin (ERY) (81\%) and 
clarithromycin (CLA) (32\%). (Table 5). MICs were performed according to CLSI guidelines (tests repeated two times). MICs were interpreted according to the IES kit criteria (see the legend to Table 5) [8].

Table 5. Antibiotic susceptibility of the $U$. urealyticum isolates with IES kit: MIC $(\mu \mathrm{g} / \mathrm{mL})$

\begin{tabular}{|c|c|c|c|c|}
\hline & \multicolumn{2}{|c|}{ U.urealyticum $\left(\mathrm{n}^{1}=82\right)$} & \multicolumn{2}{|c|}{$M I C(\mu g / m L)$} \\
\hline & $S$ & $R$ & $S$ & $R$ \\
\hline Pristinamycin (PRI) & $82(100.0)$ & $0(0)$ & \multicolumn{2}{|c|}{$\frac{1}{\geq 2}$} \\
\hline Minocycline (MIN) & $56(68.5)$ & $26(31.5)$ & $\leq 2$ & $\geq 8$ \\
\hline Josamycin (JOS) & $78(95.0)$ & $4(5.0)$ & $\leq 2$ & $\geq 8$ \\
\hline Erythromycin (ERY) & $66(81.0)$ & $16(19.0)$ & $\leq 8$ & $\geq 16$ \\
\hline Roxythromycin (ROX) & $60(74.0)$ & $22(26.0)$ & $\leq 1$ & $\geq 4$ \\
\hline Clindamycin (CLI) & $0(0.00)$ & $82(100.0)$ & $\leq 0.25$ & $\geq 0.5$ \\
\hline Ofloxacin (OFL) & $56(68.7)$ & $26(31.3)$ & $\leq 1$ & $\geq 4$ \\
\hline Ciprofloxacin (CIP) & $77(94.0)$ & $5(6.0)$ & $\leq 1$ & $\geq 2$ \\
\hline Clarythromycin (CLA) & $56(68.0)$ & $26(32.0)$ & $\leq 1$ & $\geq 4$ \\
\hline Tetracycline (TET) & $66(80.0)$ & $16(20.0)$ & $\leq 1$ & $\geq 2$ \\
\hline Levofloxacin (LEV) & $59(72.0)$ & $23(28.0)$ & $\leq 2$ & $\geq 4$ \\
\hline
\end{tabular}

Mycoplasma IES kit (Autobio).U.urealyticum, Ureaplasma urealyticum; S, susceptible; I, intermediate; R, resistant. $n^{1}=82$ (patient). Results are $n(\%)$. The breakpoints $(\mu \mathrm{g} / \mathrm{mL})$ according to the Clinical and Laboratory Standards Institute are as follows: Tetracycline $S \leq 1, R \geq 2$; Minocycline $S \leq 2, R \geq 8$; Roxythromycin $S \leq 1, R \geq 4$ Clarythromycin $S \leq 1, R \geq 4$; Erythromycin $S \leq 8, R \geq 16$; Josamycin $S \leq 2, R \geq 8$; Ciprofloxacin $S \leq 1, R \geq 2$; Ofloxacin $S \leq 1, R \geq 4$; Clindamycin $S \leq 0.25$, $R \geq 0.5$; Levofloxacin $S \leq 2, R \geq 4$; Pristinamycin $R \geq 2$. (30).

Mycoplasmas are microorganisms that can be in the oral and genital system of humans but can form a disease with the effect of certain factors. The most common mycoplasmas isolated from the urogenital system are M. hominis and $U$. urealyticum in many studies [9].

Ureaplasmas have also been consistently associated with Nongonococcal Urethritis (NGU) and pregnancy complications [10]. U. urealyticum is an opportunistic pathogen in humans and can often be isolated from the genitourinary system of young women, causing diseases such as acute urethritis, bacterial vaginitis, pelvic inflammatory disease, and pyelonephritis. It can cause miscarriage in pregnant women and chorioamnionitis and congenital pneumonia in infants, and it can be isolated from the fetus and cerebrospinal fluid. It is also known to cause infertility in women $[11,12]$.

It has become a necessity to use effective and rapid diagnostic methods to control these infections and reduce their complications because of the pathogenic role of ureaplasmas is increasing [12, 13]. Mycoplasma IES and Mycoplasma IST-2 kits are commercial test kits that are used for Ureaplasma spp. detection and give faster results compared to the culture method.

In this study, it was found that the sensitivity of the IES kit was higher than the IST-2 kit, and the sensitivity rates were found to be $80.56 \%$ and $72.22 \%$, respectively. Regarding antibiotic sensitivity, the conformity rate between Mycoplasma IES and Mycofast Revolution has been reported as 100\% [14, 15]. In our study, the concordance rate between IES and IST 2 was determined as $100 \%$ for both samples 
and it is compatible with the study data. Similarly, D'Inzeo et al. (2017) compared the sensitivities of Mycoplasma IES, Mycoplasma IST 2 and Mycofast, and they found the sensitivity results as 100\%, 95.3\% and 96.2\%, respectively, and reported the highest result for Mycoplasma IES [13]. In a study by Kusanovic et al. (2020), the sensitivity of Mycoplasma IES, MYCOFAST RevolutioN and Mycoplasma IST 2 kits was determined as 100\%, 96 and 95\% for U. urealyticum, respectively, and it is consistent with the results we obtained from this study [16].

The $U$. urealyticum detection rate was found to be $61 \%$ with IES, $52 \%$ with the IST-2 kit, and $74 \%$ with the culture method in our study. Skiljevic et al. (2016) reported the rate of detection of $U$. urealyticum in urethral and endocervical swab samples as $77.8 \%$ in their study with IST-2 and including 132 female patients [17]. In another study using IST-2; 9956 sample was included in the study, and 1856 of them were found to be positive. U. urealyticum was detected in 1652 patients (89\%) among these positives [18]. In our study, U. urealyticum detection rate (52\%) was found with the IST-2 kit, and it was concluded that this difference may be due to factors such as living conditions, socioeconomic status, and age.

The other aim of this study was to compare the effectiveness of commercial mycoplasma kits for different clinical samples including vaginal and urine. The results of the sensitivity study performed with different samples with these three methods were IES (97.22\%), IST2 (88.89\%) and culture method (100\%) for vagina, while the data for urine were $63.89 \%, 55.56 \%$ and $100 \%$. The rate of detecting $U$. urealyticum with the IES kit was significantly higher than the IST-2 kit for both samples $(\mathrm{p}<0.001)$. In our literature survey, no study was found that determined these two kits in comparison with two different sample types.

In most clinical studies, it appears that the presence of $U$. urealyticum was usually determined by studying a single biological sample. It was concluded that the vaginal sample was a more suitable material for the detection of $U$. urealyticum than the urine sample, and no significant difference was found in the antibiotic sensitivity tables.

In our study, antibiotic resistance rates measured by IES were found to be ciprofloxacin, $6.0 \%$, clindamycin $100 \%$, levofloxacin $28.0 \%$, ofloxacin $31.3 \%$, tetracycline $20 \%$, clarithromycin $32.0 \%$, erythromycin $11.1 \%$, minocycline $31.5 \%$ and roxithromycin $26 \%$. Similarly, antibiotic resistance rates in Tuzemen et al. study (2017) with IES were reported as ciprofloxacin $84.65 \%$, clindamycin $85.96 \%$, levofloxacin $15.35 \%$, ofloxacin $23.49 \%$, tetracycline $19.42 \%$, clarithromycin $12.6 \%$, erythromycin $14.96 \%$, minocycline $0.39 \%$ and roxithromycin $13.39 \%$ [12]. Longdoh et al. (2018) found $U$. urealyticum detection rate $78.57 \%$ in their study performed by IES kit from cervical specimens in pregnant women, and reported antibiotic susceptibilities as $72.4 \%, 93.1 \%$ and $41.3 \%$ for erythromycin, ciprofloxacin and tetracycline, respectively [19]. When these results were evaluated, it was seen that the sensitivity rates in the samples taken from the cervical swabs were similar. 
Likewise, the results obtained from the studies conducted with IST-2 in the literature are compatible with our study. In the study conducted by Koh et al. (2009) with the IST2 kit, the antibiotic sensitivity rates were found to be tetracycline $81 \%$, erythromycin $82.9 \%$, ofloxacin $56.2 \%$ and pristinamycin 100\% [20]. While Jang et al. (2019) in their studies, the sensitivities of U. urealyticum to doxycycline, erythromycin, ciprofloxacin and azithromycin were determined as $94.8 \%, 87.9 \%, 5.2 \%$ and $81 \%$, respectively [21].

In the study performed by Skiljevic et al. (2016) with the IST2 kit, the resistance rate to erythromycin was determined as $83.8 \%$, and it shows an inverse correlation with our resistance rate (11\%) that we determined with the IST2 kit [17]. In other studies, conducted by Bayraktar et al. (2010) and Tüzemen et al. (2017) resistance rates against erythromycin are similar to our study with $22.2 \%$ and $14.36 \%$, respectively $[12,22]$. All these differences can be attributed to differences in the local use of antibiotics.

Recent studies support the use of commercially available kits for the diagnosis of Ureaplasma spp. The use of kits is preferred to determine the frequencies of U. urealyticum and M. hominis in urine and other biological samples as well as vaginal and endocervical fluid, and antibiotic susceptibility profiles, especially against tetracyclines and fluoroquinolones.

As a result, it was found that the detection rate of the culture method was superior to both kits and concluded that the detection rate of the IES kit was higher in both samples. The IES kit can be preferred over the IST2 kit, considering the high rate of detection, availability, and price. Our findings will be useful in terms of being guide on clinical studies to be conducted on U. urealyticum.

\section{ACKNOWLEDGEMENTS}

We thank the doctors and nurse at Baskent University Ankara Hospital for Obstetrics and Gynecology Clinic and Prof.Dr. Polat Dursun.

\section{AUTHOR CONTRIBUTIONS}

Concept: Ş.Ö., S.Y.; Design: Ş.Ö.; Control: S.Y.; Sources: Ş.Ö.; Materials: Ş.Ö., S.Y.; Data collection and/or processing: Ş.Ö., S.Y.; Analysis and/or interpretation: Ş.Ö., S.Y.; Literature review: Ş.Ö., S.Y.; Manuscript writing: Ş.Ö., S.Y.; Critical review: Ş.Ö., S.Y.; Other: Ş.Ö., S.Y.

\section{CONFLICT OF INTEREST}

The authors declare that there is no real, potential, or perceived conflict of interest for this article. 


\section{ETHICS COMMITTEE APPROVAL}

Ankara University Faculty of Medicine Clinical Research Ethics Committee. No: 12-500-13. 26.08.2013.

\section{REFERENCES}

1. Ozturk, S., Yildiz, S., Dursun, P., Yener Ilce, B., Kaymaz, O. (2019). Mycoplasma hominis profile in women: Culture, kit, molecular diagnosis, antimicrobial resistance, and treatment. Microbial Pathogenesis, 135, 103635. [CrossRef]

2. $\quad$ Song, T., Liu, Z., Zhang, Y., Han, Y., Huang, J. (2019). Detection of Ureaplasma spp. serovars in genital tract of infertile males. Journal of Clinical Laboratory Analysis, 33(5), e22865. [CrossRef]

3. Lee, J.Y., Yang, J.S. (2020). Prevalence and antimicrobial susceptibility of Mycoplasma hominis and Ureaplasma Species in nonpregnant female patients in South Korea indicate an increasing trend of pristinamycin-resistant isolates. Antimicrobial Agents and Chemotherapy, 64(10), e106520. [CrossRef]

4. Miyoshi, Y., Suga, S., Sugimi, S., Kurata, N., Yamashita, H., Yasuhi, I. (2020). Vaginal Ureaplasma urealyticum or Mycoplasma hominis and preterm delivery in women with threatened preterm labor. The Journal of Maternal-Fetal\&Neonatal Medicine, 1-6. [CrossRef]

5. Edward, D.G. (1954). The pleuropneumonia group of organisms: a review, together with some new observations. Microbiology, 10(1), 27-64. [CrossRef]

6. Altındiş, M., Tanır, H.M. (2001). Vajinal akıntısı olan kadınlarda Mycoplasma hominis ve Ureaplasma urealyticum sıklığının ve antimikrobiyallere direnç durumlarının saptanması. Türk Hijyen ve Deneysel Biyoloji Dergisi, 58(1), 15-20.

7. Shepard, M.C., Lunceford, C.D. (1970). Urease color test medium U-9 for the detection and identification of "T" mycoplasmas in clinical material. Applied Microbiology, 20(4), 539.

8. Wayne, P. (2011). Clinical and laboratory standards institute. Performance standards for antimicrobial susceptibility testing.

9. Zhao, F., Feng, X., Lv, P., Xu, X., Zhao, Z. (2020). Real-time PCR assay may be used to verify suspicious test results of Ureaplasmas spp. from the liquid culture method. Journal of Microbiological Methods, 169, 105831. [CrossRef]

10. Frølund, M., Björnelius, E., Lidbrink, P., Ahrens, P., Jensen, J.S. (2014). Comparison between culture and a multiplex quantitative real-time polymerase chain reaction assay detecting Ureaplasma urealyticum and U. parvum. PLoS One, 9(7), e102743. [CrossRef]

11. Sleha, R., Boštíková, V., Hampl, R., Salavec, M., Halada, P., Štěpán, M., Novotná, Š., Kukla, R., Slehová, E., Kacerovský, M., Boštík, P. (2016). Prevalence of Mycoplasma hominis and Ureaplasma urealyticum in women undergoing an initial infertility evaluation. Epidemiologie, Mikrobiologie, Imunologie, 65(4), 232-237. 
12. Tüzemen, N.Ü., Efe, K., Özakın, C. (2019). Mycoplasma hominis ve Ureaplasma urealyticum: Ürogenital Sistem İnfeksiyonlarındaki Yeri ve Antibiyotik Direnç Oranlarının Retrospektif Olarak Değerlendirilmesi. Klimik Dergisi, 32(1), 40-45. [CrossRef]

13. D'Inzeo, T., De Angelis, G., Fiori, B., Menchinelli, G., Liotti, F.M., Morandotti, G.A., De Maio, F., Nagel, D., Antonaci, M., Sanguinetti, M., Spanu, T. (2017). Comparison of Mycoplasma IES, Mycofast Revolution and Mycoplasma IST2 to detect genital mycoplasmas in clinical samples. The Journal of Infection in Developing Countries, 11(1), 98-101. [CrossRef]

14. Kilic, D., Basar, M.M., Kaygusuz, S., Yilmaz, E., Basar, H., Batislam, E. (2004). Prevalence and treatment of Chlamydia trachomatis, Ureaplasma urealyticum, and Mycoplasma hominis in patients with non-gonococcal urethritis. Japanese Journal of Infectious Diseases, 57(1), 17-20.

15. Nulens, E., Van Praet, J., Selleslag, D., Van Landschoot, T., Dekeyzer, D., Descheemaecker, P., Reynders, M. (2016). A disseminated Mycoplasma hominis infection in a patient with an underlying defect in humoral immunity. Infection, 44(3), 379-381. [CrossRef]

16. Kusanovic, J.P., Vargas, P., Ferrer, F., Díaz, F., Córdova, V., Martinovic, C., Valdés, R., Rosas, A., Luna, D., Silva, P., Silva, K., Nilo, M.E., Silva, M.J., Espejo, E., Zambrano, M.A., García, J., Parra-Lara, L.G., Escobar, M.F. (2020). Comparison of two identification and susceptibility test kits for Ureaplasma spp and Mycoplasma hominis in amniotic fluid of patients at high risk for intra-amniotic infection. The Journal of Maternal-Fetal \& Neonatal Medicine, 33(20), 34093417. [CrossRef]

17. Skiljevic, D., Mirkov, D., Vukicevic, J. (2016). Prevalence and antibiotic susceptibility of Mycoplasma hominis and Ureaplasma urealyticum in genital samples collected over 6 years at a Serbian university hospital. Indian Journal of Dermatology, Venereology and Leprology, 82(1), 37-41. [CrossRef]

18. De Francesco, M.A., Caracciolo, S., Bonfanti, C., Manca, N. (2013). Incidence and antibiotic susceptibility of Mycoplasma hominis and Ureaplasma urealyticum isolated in Brescia, Italy, over 7 years. Journal of Infection and Chemotherapy, 19(4), 621-627. [CrossRef]

19. Longdoh, N.A., Gregory, H.E.E., Djeumako, W.A., Nguedia, A.J.C., Francois-Xavier, M.K., Tebit, K.E. (2018). The occurrence and antimicrobial susceptibility patterns of Mycoplasma hominis and Ureaplasma urealyticum in pregnant women in three district hospitals in Douala, Cameroon. Journal of Advances in Medicine and Medical Research, 1-11. [CrossRef]

20. Koh, E., Kim, S., Kim, I.S., Maeng, K.Y., Lee, S. (2009). Antimicrobial susceptibilities of Ureaplasma urealyticum and Mycoplasma hominis in pregnant women. Korean Journal of Clinical Microbiology, 12(4), 159-162. [CrossRef]

21. Jang, Y.S., Min, J.W., Kim, Y.S. (2019). Positive culture rate and antimicrobial susceptibilities of Mycoplasma hominis and Ureaplasma urealyticum. Obstetrics \& Gynecology Science, 62(2), 127-133. [CrossRef]

22. Bayraktar, M.R., Ozerol, I.H., Gucluer, N., Celik, O. (2010). Prevalence and antibiotic susceptibility of Mycoplasma hominis and Ureaplasma urealyticum in pregnant women. International Journal of Infectious Diseases, 14(2), e90-95. [CrossRef] 